\title{
Halal Reputation Management: Combining Individual and Collective Reputation Management Strategies
}

\author{
Marco Tieman*
}

A series of recent high-profile halal scandals involving top brands have shown that halal reputation and Muslim consumer loyalty can change very quickly. It seems that companies are under continuous scrutiny. Unfortunately, companies frequently only find out the actual value of their halal reputation when they manage a halal issue or crisis poorly. Even though halal reputation is hard to define and value, it is evidently critical to track its performance. Today, many companies do not have these new halal reputation risks on their radar.

There is a wide diversity in awareness and adoption of the halal concept among companies. At the same time, there is an evident increase in halal awareness among Muslim consumers. ${ }^{1}$ Halal issues in the supply chain, whether intentional or unintentional, can lead to a complete breakdown in consumer trust. ${ }^{2}$ Today, Muslim consumer has high demands and shares information quickly. Attitudes towards global brands have changed; The spotlight is on halal reputation performance.

In line with an integrative view of reputation management as described by Fombrun and Van $\mathrm{Riel}^{3}$, I propose the following definition of halal reputation: $A$ corporate halal reputation is a collective representation of the firm's past actions and halal performance, and the firm's future ability to meet halal requirements. Halal reputation is a firm's overall appeal to its key stakeholders, foremost the Muslim consumer. This viewpoint discusses reputation management strategies for companies dealing with halal products and services.

\section{The Drivers of a Company's Halal Reputation}

Various drivers contribute to the strength of a company's halal reputation. Amongst the most influential are: halal authenticity; trustworthiness of halal certification; messages by the company and its supply chain partners; and messages by external stakeholders. These drivers interact with each other and determine the halal reputation performance of a company.

\section{Halal authenticity}

For companies to be able to connect to the Muslim community, they need to 
develop an authentic halal DNA. Halal authenticity is a function of the corporate image.

That is:

$\mathbf{H}_{\mathbf{1}}$ : The better the corporate image, and if there is a halal assurance system put in place, with risk and reputation management capabilities, the more favourable will be the halal reputation of the company.

\section{Trustworthiness of Halal Certification}

Not all halal country certifications are perceived as equally trustworthy. Moreover, the perceived trustworthiness of a halal certification often explains the the level of preference for a product. ${ }^{4}$

That is:

$\mathbf{H}_{2}$ : The higher the trustworthiness of a halal certification, the more favourable is the halal reputation of the company.

\section{Messages by company and supply chain partners}

Companies create their own negative or positive reputations primarily on the basis of what they express about their own halal reputation, irrespective of their products or services. ${ }^{5}$

That is:

$\mathbf{H}_{3}$ : The more positive a company's external messages are regarding their own halal reputation, the more favourable will be the halal reputation of that company.

\section{Messages by external stakeholders}

The most important external stakeholders are the Muslim consumers themselves. These end-consumer have easy access to modern media and can easily snowball negative messages related to their experiences. The interests of Muslim consumers can also be represented by government organisations (such as the Muslim Consumer Association of Malaysia), mosque associations in non-Muslim countries (such as Turkish Federations Netherlands), or other non-governmental organisations. A second important external stakeholder is the halal certification body that certified the brand owner. Other external stakeholders that can be influential are: governments departments (like the ministry of religious affairs or ministry of health), trade associations, other halal certification bodies, and Shariah and halal experts. 
That is:

$\mathbf{H}_{4}$ : The more negative the external messages regarding a company's halal reputation, the lower is the halal reputation of the company.

\section{Individual Reputation Management Strategies}

What the previous section shows is that three quarters of the drivers behind the halal reputation of a company are within the control of the company itself. This means that brand owners are to a very large extent, in control of their halal reputations, provided they employ a solid reputation management mechanism. Effective reputation management requires a sound prevention-mitigationrecovery system. The components of this reputation management mechanism are as follows:

\section{i. Prevention}

Systems of prevention have traditionally been focused solely on the development of a halal assurance system based on the requirements set by halal certification bodies. This is a highly reactive system, based on critical control points identified in the internal supply chain. What about addressing the critical control points in the external supply chain? Is risk and reputation management at the heart of the halal business? A reactive system leaves the company highly exposed to a halal issue and crisis.

\section{ii. Mitigation}

Halal issue management must, when things go wrong, act efficiently-it must quickly seek assessments from internal halal auditors, make decisions quickly and communicate them (internally and externally) rapidly, and quickly move to isolate the issue. This type of speed is only possible with extensive plans and practice.

\section{iii. Recovery}

The main objective of recovery is to restore the reputation or social capital of a brand. ${ }^{6}$ Public trust in the halal integrity of a product requires public reconfirmation from the halal certification body that the product is halal. This is an important statement, which needs to be communicated extensively by the brand owner. Islamic values need to be reemphasised by the brand owner via their conducting of the necessary rituals in unison with the religious schools of thought and local customs, ${ }^{7}$ which also need to be communicated extensively by the brand owner. As with mitigation, effective recovery is only possible with plans that are extensively practiced. 


\section{Collective Reputation Management Strategies}

Halal scandals involving individual firms may cast an entire industry into disrepute, just as positive publicity may enhance the industry's halal reputation. Therefore, collective halal reputation management, including all activities and behaviour undertaken by members of a collective to deliberately alter judgments about the reputation of that collective, are also an important element in reputation management.

Although it can be argued that competitive industries prefer to focus on individual reputation management strategies and limit any potential free riders, the costs of a halal crisis are very difficult to determine. Activities include information sharing, joint research and development, establishing codes of conduct, lobbying through trade associations and performing industry-level public relations and advertising. ${ }^{8}$

\section{Conclusion and Recommendation}

Halal reputation has been defined as a collective representation of a company's past actions and halal performance, as well as that company's future ability to meet halal requirements. The drivers of a company's halal reputation are: halal authenticity; the trustworthiness of a halal certification; messages delivered by companies and supply chain partners; and messages by external stakeholders.

A change in corporate mindset is required to put halal reputation management at the heart of business. ${ }^{9}$ Based on the drivers of halal reputation, companies need to track their halal reputation performance and make this a key performance indicator of their business. Instead of a reactive system, based on contemporary compliance with the requirements of a particular halal certification body, a move towards a more proactive integrated approach of halal reputation management is required. Combining individual and collective reputation management strategies enhances both risk avoidance and responsiveness during a halal crisis.

Governments and halal certification bodies carry a heavy responsibility and obligation to limit the reputation damage to companies that have the right intentions with regard to halal assurance. This requires speedy action by government authorities and halal certification bodies during halal incidents. Therefore, and similar to companies, governments and halal certification bodies also require extensive 'corporate halal crisis' plans and effective organisation in place to support industries during a halal crisis.

To bring attention to this important topic, a closed-door Halal Reputation Forum for key halal certifiable industries, namely, food, cosmetics, and pharmaceuticals, should be organised. 
* Marco Tieman is Adjunct Professor with Universiti Tun Abdul Razak (Malaysia), where he is responsible for research in halal supply chain management. He obtained his Master's degree in industrial engineering with the University of Twente (the Netherlands) in 1997 and his PhD in business management with Universiti Teknologi MARA (Malaysia) in 2013. He is also the CEO of LBB International, an international logistics consultancy and research firm specialising in halal supply chain management and halal clusters. He chaired the development of the international halal logistics standard (IHIAS, 0100:2010) under the ICCIIHI Alliance. Dr. Marco Tieman can be contacted at: marco@lbbinternational. com.

\section{Notes}

1. Nor Sara Nadia Muhamad Yunus, Wan Ezura Wan Rashid, Norafifa Mohamad Ariffin and Norhidayah Mohd Rashid, "Muslim's Purchase Intention towards Non-Muslim's Halal Packaged Food Manufacturer", Procedia-Social and Behavioral Sciences, Vol. 130 (15 May 2014), 145-54. Nor Ardyanti Binti Ahmad, Tunku Nashril bin Tunku Abaidah and Mohd Helmi bin Abu Yahya, "A Study on Halal Food Awareness among Muslim Customers in Klang Valley", in The $4^{\text {th }}$ International Conference on Business and Economic Research ( $^{\text {th }}$ ICBER 2013) Proceeding (2013), 1073-87.

2. Marco Tieman, "Halal Certification Procedures: Some Unresolved Issues", Islam and Civilisational Renewal (ICR), Vol. 6 No.1 (January 2015): 124-7.

3. Charles Fombrun and Cees van Riel, "The Reputational Landscape", Corporate Reputation Review, Vol. 1 Nos. 1\&2 (1997): 1-16.

4. Rosa E. Rios, Hernan E. Riquelme, and Yasser Abdelaziz, "Do Halal Certification Country of Origin and Brand Name Familiarity Matter?" Asia Pacific Journal of Marketing and Logistics, 26(5) (2014): 665-86.

5. C.B.M. van Riel, "Future Trends in Reputation Management", RSM Discovery Management Knowledge, Vol. 19 No. 3 (2014): 5-7.

6. Yuko Nakagawa and Rajib Shaw, "Social Capital: A Missing Link to Disaster Recovery", International Journal of Mass Emergencies and Disasters, Vol. 22 No.1 (March 2004): 5-34.

7. Marco Tieman, "The Application of Halal in Supply Chain Management: Indepth Interviews", Journal of Islamic Marketing, Vol. 2 No. 2 (2011): 186-95.

8. Monika I. Winn, Patricia MacDonald, and Charlene Zietsma, "Managing Industry Reputation: The Dynamic Tension between Collective and Competitive Reputation Management Strategies", Corporate Reputation Review, Vol. 11 No.1 (2008): 35-55.

9. Andrew Griffin, New Strategies for Reputation Management: Gaining Control of Issues, Crises \& Corporate Social Responsibility (London: Kogan Page, 2007). 